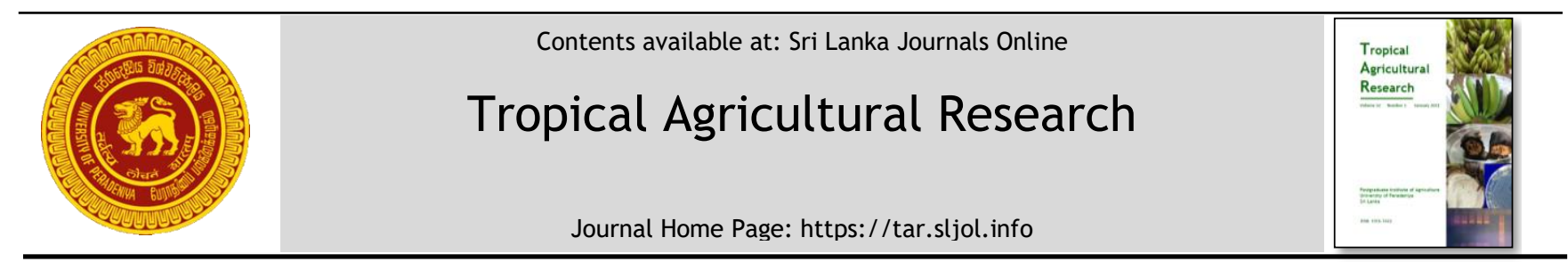

\title{
Probiotic Viability and Physicochemical Properties of Set-Yoghurt Made of Indigenous and Exotic Cow Milk
}

\author{
W.V.V.R. Weerasingha ${ }^{1}{ }^{*}$, C.S. Ranadheera ${ }^{2}$, P.H.P. Prasanna ${ }^{3}$, G.L.L.P. Silva ${ }^{3}$ and J.K. Vidanarachchi ${ }^{3}$ \\ ${ }^{1}$ Postgraduate Institute of Agriculture, University of Peradeniya, Peradeniya, Sri Lanka. \\ ${ }^{2}$ School of Agriculture and Food, Faculty of Veterinary and Agricultural Sciences, University of Melbourne, Australia. \\ ${ }^{3}$ Department of Animal Science, Faculty of Agriculture, University of Peradeniya, Peradeniya, Sri Lanka.
}

\section{ARTICLE INFO}

\section{Article history:}

Received: 18 July 2020

Revised version received: 13 October 2020

Accepted: 05 November 2020

Available online: 1 January 2021

\section{Keywords:}

Cattle breeds

Lankan cattle

Solid-non-fat

Syneresis

\section{Citation:}

Weerasingha, W.V.V.R., Ranadheera, C.S., Prasanna, P.H.P., Silva, G.L.L.P. and Vidanarachchi, J.K. (2021). Probiotic Viability and Physicochemical Properties of Set-Yoghurt Made of Indigenous and Exotic Cow Milk. Tropical Agricultural Research, 32(1): 39-48.

DOI: http://doi.org/10.4038/tar.v32i1.8440

Weerasingha, W.V.V.R.

https://orcid.org/0000-0002-5234-8266

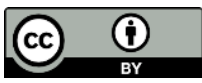

\section{ABSTRACT}

The current study was performed to assess the viability of probiotic bacteria and physicochemical properties of setyoghurt made of milk obtained from two indigenous cattle types [Thamankaduwa white (TW) and Lankan cattle] and two exotic cattle breeds [Jersey and Friesian] rearing in Sri Lanka. Milk samples $(n=180)$ were collected from individual cattle representing 15 cows per each cattle breed/type. Milk composition of each cattle breed/type was analyzed and setyoghurts were prepared using composite milk samples from each cattle breed/type. Starter culture composed of Streptococcus thermophilus, Lactobacillus delbrueckii ssp. bulgaricus and Bifidobacterium animalis ssp. lactis (BB-12) was used. Total viable counts of yoghurt bacteria and probiotic bacteria, titratable acidity, $\mathrm{pH}$ and syneresis were measured to evaluate the quality attributes of set-yoghurt throughout the storage period of 21 days at $4{ }^{\circ} \mathrm{C}$. Cattle breed/type had an evident effect on milk composition in relation to milk fat and total solids content. Friesian cattle had the lowest $(\mathrm{p}<0.05)$ fat content while TW cattle and Lankan cattle showed significantly higher total solids contents compared to Friesian and Jersey. Yoghurt made of two indigenous cattle types showed the highest $(\mathrm{p}<0.05)$ viability for yoghurt bacteria and probiotic bacteria and all set-yoghurts consisted of minimum therapeutic level of probiotic bacteria throughout the entire storage period of 21 days at $4{ }^{\circ} \mathrm{C}$. Significantly lower $(\mathrm{p}<0.05)$ syneresis was observed in the set-yoghurt produced using TW and Lankan cattle milk while the highest syneresis was observed in the set-yoghurt produced with Friesian milk. Superior milk composition, higher probiotic viability and better technological properties of setyoghurt made of indigenous cow milk suggest the potential use of indigenous cow milk in development of probiotic dairy products supporting the Sri Lankan dairy industry and conservation of valuable local cattle gene pool of the country.

*Corresponding author : wvvirajroshan7@gmail.com 


\section{INTRODUCTION}

Fermented dairy products are healthy and nutritious foods consumed by the people around the world as a part of diet. Consumption of fermented dairy products has been remarkably increased compared to the consumption of liquid milk over the past few decades. Many novel trends have been created in fermented dairy processing industry due to their promising health benefits especially as a probiotic carrier food and other functional properties (Korhonen, 2009; Surono and Hosono, 2011; Carić et al., 2019). Dairy products made from milk of indigenous cattle breeds are highly appreciated by the healthconscious consumers as milk from these breeds provide distinctive health benefits, better rheological and organoleptic properties (Summer et al., 2002; Duclos and Hiemstra, 2010).

Milk from different cattle breeds have different compositional profiles depending on their genetic makeup (Poulsen et al., 2012). The protein and fat contents of raw milk are mainly dependent on the genetic variations of the cattle breed (Duclos and Hiemstra, 2010). The rheological properties of milk are closely related with texture and stability of the dairy products and also depend on the milk composition, which is mainly determined by the milk protein genetic variants (Abeykoon et al., 2016; Bergamaschi et al., 2016). In Sri Lanka, mainly two indigenous cattle types can be identified including Lankan/"Battu" cattle and White/Thamankaduwa white cattle (TW) (Felius, 1995; Silva et al., 2008). Indigenous cattle types are poor in milk production and confined to small populations in few places of the country but well adapted to the local environmental conditions (Silva et al., 2008). Even though they are poor milk producers, there is a higher demand for the dairy products made of indigenous breeds due to the firm curd structure, distinctive flavour and therapeutic properties (Reddy et al., 2016; Silva et al., 2019). As per the traditional believes of the Sri Lankans, milk from indigenous cows is free from milk proteins which cause the cow milk allergy in human (Chandrasiri, 2002; Silva et al., 2019). Under most of the animal breeding programs conducted over the past years, more reliance is being placed on few of the high producing breeds which require high input systems while the valuable indigenous genetic resources are still idling (Haile et al., 2011). Most of the indigenous cattle breeds are now threatened, as a result of the continuous introduction of exotic germplasm in breed improvement programs, without considering the conservation of indigenous breeds (Chandrasiri, 2002; Islam et al., 2014).
Therefore, the development of fermented dairy products from local cattle milk and evaluation of their distinctive technological and functional attributes may contribute to an increase in indigenous cattle population among low input extensive rearing systems of the country, which can ultimately help preventing extinction of indigenous cattle breeds of the country. Among the fermented dairy products consumed by Sri Lankans, set-yoghurt is the most demanded. Yoghurt is a highly nutritious fermented food product which delivers ample health benefits due to the potential probiotic properties of starter bacteria (Ranadheera et al., 2012; Sloan, 2014). Therefore, the first objective of this study was to compare the viability of yoghurt bacteria and probiotic bacteria in set- yoghurt made of indigenous cow milk (Lankan cattle and TW cattle) and most common two exotic cattle breeds reared in Sri Lanka (Jersey and Friesian). In addition, milk composition including milk fat, protein, lactose and solid-non-fat (SNF) content of TW and Lankan cattle raised under low input- extensive management system was compared with Jersey and Friesian raised under semi-intensive management systems in dry zone of Sri Lanka as the second objective of the study.

\section{MATERIALS AND METHODS}

\section{Collection of milk samples}

One hundred and eighty (180) fresh whole milk samples were collected from 60 individual cattle including TW $(n=15)$, Lankan cattle $(n=15)$, Jersey $(n=15)$ and Friesian $(n=15)$. For each cattle breed/type, $7.5 \mathrm{~L}$ of milk was collected per one sampling day by sampling $500 \mathrm{~mL}$ of milk per each animal. Milk collection was repeatedly done on three sampling days per each cattle breed/type. Milk of TW cattle was collected from Trincomalee and Welikanda areas while Lankan cattle milk was collected from Neriyakulam and Madawachchiya area. Jersey and Friesian milk were collected from Thalawa, Kekirawa and Saliyapura area. All the areas employed in the milk collection belong to the dry zone of Sri Lanka. Jersey and Friesian cows included in this study are raised under semiintensive system and Lankan cattle and TW cattle are raised under the extensive management system. All the cattle were in their second parity and mid lactation stage. Milk samples were stored in ice immediately after collection at $4 \pm 1{ }^{\circ} \mathrm{C}$ and processed within 24 hours of sampling.

\section{Analysis of milk composition}

Whole milk samples were analyzed for total milk protein, milk fat, SNF and lactose contents using a 
Lactoscan SP standard milk analyzer (Lactoscan SP, Bulgaria).

\section{Preparation of set-yoghurts}

Commercial starter cultures purchased from $\mathrm{Chr}$. Hansen Company (Chr. Hansen, Horsholom, Denmark) were used in this study. Freeze dried thermophilic yoghurt starter culture (YF-L903) containing Streptococcus thermophilus and Lactobacillus delbrueckii ssp. bulgaricus and probiotic culture which contain Bifidobacterium animalis ssp. lactis (BB-12) (ABY-10) were inoculated in set-yoghurt preparation as per the manufacturer's instructions.

Fresh whole milk was standardized up to $2.5 \%$ $(\mathrm{w} / \mathrm{v})$ fat level and subjected to preheating at 55$60{ }^{\circ} \mathrm{C}$ followed by homogenization at $55^{\circ} \mathrm{C}$ for 15 minutes under 10-20 MPa using a laboratory-scale homogenizer (Kunal International, India). Pasteurization of milk was done at $80-85^{\circ} \mathrm{C}$ for 30 minutes (Madhubasani et al., 2020). Thermophilic yoghurt culture and BB-12 probiotic culture were inoculated when milk was cooled down to $42{ }^{\circ} \mathrm{C}$ temperature. Incubation was done at $42 \pm 2{ }^{\circ} \mathrm{C}$ temperature for 4 hours and stored in a refrigerator at $4 \pm 1{ }^{\circ} \mathrm{C}$. For each cattle breed/type; 15 replicates were used including 5 yoghurt replicates per each day of sampling for the analysis of $\mathrm{pH}$, titratable acidity, syneresis and probiotic counts. Enumeration of yoghurt bacteria and probiotic counts were done at day 1, 7, 14 and 21 .

\section{Microbiological analysis}

Initial viable bacterial counts of pasteurized milk from all four breeds were enumerated using plate count agar (Sigma-Aldrich, Saint Louis, USA). Incubation of the plates were done at $37 \pm 2{ }^{\circ} \mathrm{C}$ for 24 hours.

The growth and viability of the $S$. thermophilus, $L$. delbrueckii ssp. bulgaricus and B. animalis ssp. lactis were evaluated using a serial dilution of yoghurts. The enumeration of each bacteria was carried out using the appropriate selective agar media and conditions as described by Donkor et al. (2007). M17 agar medium (Sigma-Aldrich, Saint Louis, USA) was used for the enumeration of $S$. thermophilus count and incubation was done at $37 \pm 2{ }^{\circ} \mathrm{C}$ for 48 hours under aerobic conditions. $L$. delbrueckii ssp. bulgaricus and Bifidobacterium animalis ssp. lactis enumeration was done using MRS agar and Bifidobacterium selective medium (BSM), respectively (Sigma-Aldrich, Saint Louis, USA). Incubation of the plates were done at $37 \pm 2^{\circ} \mathrm{C}$ for 72 hours under anaerobic conditions created with anaerobic jars using anaerobic gas packs (Oxoid AnaeroGen, Thermo Fisher Scientific, USA).

\section{Physicochemical analysis of set-yoghurt Determination of $\mathrm{pH}$ and titratable acidity}

The $\mathrm{pH}$ values of the set-yoghurts were determined using a digital pH meter (SensION, E-08328, Spain). The titratable acidity of the set-yoghurt during the storage period was estimated by titration with $0.1 \mathrm{~N} \mathrm{NaOH}$ solution using phenolphthalein as the indicator (Azari-Anpar et al., 2017).

\section{Syneresis}

Syneresis was measured according to the method described by Dannenberg and Kessler (1988) with slight modifications. Set-yoghurt portion of $20 \mathrm{~g}$ (Y) which was taken without disturbing the yoghurt coagulum was placed on Whatman No.1 filter paper and allowed to drain the whey for 1 hour. The drained whey volume (DW) was measured after 1 hour and syneresis percentage was expressed according to the formula given below.

$$
\text { Syneresis }(\%)=100(D W / Y)
$$

\section{Statistical analysis}

Milk composition data of each cattle breed/type were analyzed by using Nested Completely Randomized Design (Nested CRD). The viability of yoghurt and probiotic bacteria throughout the shelf life was analysed using one-way ANOVA while mean separation was done using Tukey's test with MINITAB (version19) software. Similarly, pH, syneresis, titratable acidity data of set-yoghurts were analysed using one-way ANOVA.

\section{RESULTS AND DISCUSSION}

Cattle breed or genotype (Palladino et al., 2010), environmental factors (Heck et al., 2009), stage of lactation, parity (Yang et al., 2013a) and feed (Welter et al., 2016) are the major factors which influence the bovine milk composition. Cattle breed creates striking effects on milk composition and technological characteristics of milk and milk products (Yang et al., 2013b). It is well established that there is a significant variation in milk quality among cattle breeds, though little is known about the variation of milk composition among low milk yielding indigenous breeds (Cheruiyot et al., 2018). According to the milk composition analysis, cattle breed had an evident effect on milk fat and SNF content while no significant effect on milk protein and lactose content (Table 01).

The variations of the milk fat content could be attributed to the genetic variations, physiological status of the cow and quality of dietary intake (Agabriel et al., 1995; Barłowska et al., 2009; 
Murphy et al., 2016). According to the results of the current study, breed differences had significant effects on milk fat content. Fat content of the Friesian milk was lower $(\mathrm{p}<0.05)$ than the other three breeds. Similarly, lower fat content was reported in Holstein Friesian in previous studies done by Bassiri et al. (2012) and Kebede (2018) depending on the various genetic traits of the cattle breeds. According to a study conducted in Poland, Barlowska et al. (2006) found that the milk obtained from the two native cattle breeds had the fatty acid ratio most beneficial for human nutrition than Holstein-Friesian breed which were fed with same diet. Apart from the direct effect of genetics on the quality of milk produced, quality of the dietary intake also affects milk fat and fatty acid composition (Agabriel et al., 1995). As per the results, TW cattle and Lankan cattle showed significantly higher SNF content compared to Friesian and Jersey. In agreement with the present research Abeykoon et al. (2016) also reported that TW cattle and Lankan cattle had significantly higher milk SNF content than Friesian. In this study, milk protein and lactose content showed no significant difference among the four cattle breeds/types. According to a study conducted in India, higher milk fat content and whey protein content have been reported in indigenous cows than in exotic cows while there's no significant difference in SNF and lactose content (Singh and Pratap, 2014). Contradictorily, significantly higher milk protein content has been reported in pure indigenous Ethiopian cattle compared to Holstein Friesian under same feeding and management conditions (Kebede, 2018). However, in line to the current study findings, several authors have reported extensively varied milk fat contents among different cattle breeds (Adesina, 2012; Myburgh et al., 2012). One of the primary goals of the dairy industry is to improve dairy product quality and yield through modifications of milk composition (Murphy et al., 2016). Therefore, the current study results suggest that the indigenous cattle breeds may carry some superior functional traits (i.e. composition of milk) to be considered in breed improvement programmes (Singh and Pratap, 2014; Kebede, 2018).

Initial viable bacterial counts of pasteurized milk of TW, Lankan cattle, Jersey and Friesian were $2.27 \pm 0.01,2.39 \pm 0.04 ., 2.47 \pm 0.02$ and $2.21 \pm 0.05 \mathrm{log}$ $\mathrm{cfu} / \mathrm{g}$ respectively. There was no significant $(p<0.05)$ difference among the initial viable counts of milk from different cattle types/breeds. Hence, it can be suggested that, the initial viable counts are less likely to have direct relation with the probiotic bacterial counts of the set-yoghurts. The results of viable counts of L. delbrueckii ssp. bulgaricus, $S$. thermophilus and B. animalis ssp. lactis (BB-12) in set-yoghurts are shown in Table 2 . In order to obtain the potential health benefits of the probiotic organisms, they should be administered in sufficient amounts. According to the most commonly applied recommendations in the food industry, $10^{6} \mathrm{cfu} / \mathrm{g}$ is considered as the minimum therapeutic level of probiotic bacteria to be consisted in a probiotic food item (Yilmaz-Ersan and Kurdal, 2014; Ertem and Çakmakçı, 2018). Present study results revealed that set-yoghurt made using milk of all four breeds/types had minimum therapeutic level of probiotic bacteria along entire storage period of 21 days at $4 \pm 1{ }^{\circ} \mathrm{C}$.

The viable counts of $S$. thermophilus showed a significant $(\mathrm{p}<0.05)$ difference between the indigenous and exotic breeds while all counts remained quite high during refrigerated storage of 21 days at $4 \pm 1{ }^{\circ} \mathrm{C}$. $S$. thermophilus showed the fastest growth in set-yoghurt made using milk of all four cattle breeds/types, which usually dominates the early stages of yoghurt fermentation (Shah, 2000). S. thermophilus counts in yoghurt made from TW and Lankan cattle milk increased up to day 7 and then declined while set-yoghurt made of Friesian and Jersey showed reduction of $S$. thermophilus viability over entire storage period. Among the three organisms enumerated, $S$. thermophilus was found to be the most stable organism in all set-yoghurts and its counts were $>8.27 \log \mathrm{cfu} / \mathrm{g}$ throughout the storage.

Table 1: Milk composition analysis of four different cattle breeds/types

\begin{tabular}{lcccc}
\hline Breed/Cattle type & Fat (\%) & Protein (\%) & Lactose (\%) & Solid-non-fat (\%) \\
\hline Thamankaduwa white & $4.56 \pm 0.50^{\mathrm{A}}$ & $3.20 \pm 0.32^{\mathrm{A}}$ & $4.28 \pm 0.18^{\mathrm{A}}$ & $7.89 \pm 0.15^{\mathrm{A}}$ \\
Lankan & $4.35 \pm 0.32^{\mathrm{A}}$ & $3.14 \pm 0.26^{\mathrm{A}}$ & $4.29 \pm 0.25^{\mathrm{A}}$ & $7.80 \pm 0.46^{\mathrm{A}}$ \\
Jersey & $4.13 \pm 0.5^{\mathrm{B}}$ & $3.18 \pm 0.28^{\mathrm{A}}$ & $4.11 \pm 0.79^{\mathrm{A}}$ & $7.37 \pm 1.47^{\mathrm{B}}$ \\
Friesian & $3.15 \pm 1.21^{\mathrm{C}}$ & $3.06 \pm 0.18^{\mathrm{A}}$ & $4.35 \pm 0.39^{\mathrm{A}}$ & $7.29 \pm 0.25^{\mathrm{B}}$ \\
\hline
\end{tabular}

${ }^{A B}$ Means indicate the significant difference $(p<0.05)$ separately among each milk composition parameter due to the effect of different cattle breed/type. All the values are expressed as mean \pm standard deviation 
Table 2: Changes in the viable counts of yoghurt and probiotic bacteria in set-yoghurt produced using milk from different cattle breeds/types

\begin{tabular}{|c|c|c|c|c|}
\hline \multirow{3}{*}{$\begin{array}{l}\text { Viability of yoghurt and } \\
\text { probiotic bacteria in set- } \\
\text { yoghurt }\end{array}$} & \multicolumn{4}{|c|}{ Storage Period } \\
\hline & Day 1 & Day 7 & Day 14 & Day 21 \\
\hline & $(\log \mathrm{cfu} / \mathrm{g})$ & $(\log \mathrm{cfu} / \mathrm{g})$ & $(\log \mathrm{cfu} / \mathrm{g})$ & $(\log \mathrm{cfu} / \mathrm{g})$ \\
\hline \multicolumn{5}{|l|}{ Viability of $S$. thermophilus } \\
\hline Thamankaduwa white & $9.02 \pm 0.01^{\mathrm{Aa}}$ & $9.14 \pm 0.03^{\mathrm{Aa}}$ & $8.89 \pm 0.02^{\mathrm{Aa}}$ & $8.89 \pm 0.07^{\text {Аа }}$ \\
\hline Lankan & $9.03 \pm 0.01^{\mathrm{Aa}}$ & $9.10 \pm 0.02^{\mathrm{Aa}}$ & $8.98 \pm 0.03^{\mathrm{Aa}}$ & $8.87 \pm 0.05^{\mathrm{Aa}}$ \\
\hline Jersey & $8.40 \pm 0.03^{\mathrm{Ab}}$ & $8.35 \pm 0.03^{\mathrm{Ab}}$ & $8.34 \pm 0.05^{\mathrm{Ab}}$ & $8.27 \pm 0.03^{\mathrm{Ab}}$ \\
\hline Friesian & $8.40 \pm 0.41^{\mathrm{Ab}}$ & $8.38 \pm 0.03^{\mathrm{Ab}}$ & $8.33 \pm 0.04 \mathrm{Ab}$ & $8.27 \pm 0.04 \mathrm{Ab}$ \\
\hline \multicolumn{5}{|l|}{$\begin{array}{l}\text { Viability of L. delbrueckii } \\
\text { ssp. bulgaricus }\end{array}$} \\
\hline Thamankaduwa white & $8.40 \pm 0.02^{\mathrm{Aa}}$ & $8.38 \pm 0.05^{\mathrm{Aa}}$ & $8.37 \pm 0.03^{\mathrm{Aa}}$ & $8.30 \pm 0.01^{\mathrm{Aa}}$ \\
\hline Lankan & $8.39 \pm 0.03^{\mathrm{Aab}}$ & $8.36 \pm 0.03^{\mathrm{Aa}}$ & $8.31 \pm 0.01^{\mathrm{Aa}}$ & $8.23 \pm 0.01^{\mathrm{Aa}}$ \\
\hline Jersey & $7.44 \pm 0.02^{\mathrm{Ab}}$ & $6.77 \pm 0.05^{\mathrm{Bb}}$ & $6.76 \pm 0.02^{\mathrm{Bc}}$ & $6.26 \pm 0.01^{\mathrm{cc}}$ \\
\hline Friesian & $7.99 \pm 0.03^{\mathrm{Ac}}$ & $7.45 \pm 0.03^{\mathrm{ABC}}$ & $7.71 \pm 0.03^{\mathrm{Bb}}$ & $7.39 \pm 0.02^{\mathrm{Bb}}$ \\
\hline \multicolumn{5}{|l|}{$\begin{array}{l}\text { Viability of B. animalis } \\
\text { subsp. lactis (BB-12) }\end{array}$} \\
\hline Thamankaduwa white & $8.41 \pm 0.02^{\mathrm{Aa}}$ & $8.37 \pm 0.01^{\mathrm{Aa}}$ & $8.36 \pm 0.04^{\mathrm{Aa}}$ & $8.31 \pm 0.05^{\mathrm{Aa}}$ \\
\hline Lankan & $8.37 \pm 0.02^{\mathrm{Aa}}$ & $8.34 \pm 0.02^{\mathrm{Aa}}$ & $8.27 \pm 0.03^{\mathrm{Aa}}$ & $8.17 \pm 0.03^{\mathrm{Aa}}$ \\
\hline Jersey & $7.43 \pm 0.02^{\mathrm{Ab}}$ & $7.36 \pm 0.01^{\mathrm{ABb}}$ & $7.20 \pm 0.02^{\mathrm{ABb}}$ & $6.98 \pm 0.03^{\mathrm{Bb}}$ \\
\hline Friesian & $7.11 \pm 0.02^{\mathrm{Ab}}$ & $6.87 \pm 0.02^{\mathrm{ABC}}$ & $6.52 \pm 0.01^{\mathrm{Bc}}$ & $6.11 \pm 0.01^{\mathrm{cc}}$ \\
\hline
\end{tabular}

Results are expressed as the mean \pm standard deviation. ${ }^{A B C}$ Means without common superscripts in a row are different ( $\mathrm{p}<0.05$ ). abc Means without common superscripts in a column within a particular yoghurt or probiotic bacteria are different $(\mathrm{p}<0.05)$.

Set-yoghurt made from TW and Lankan cattle milk showed better viability of probiotic bacteria since there's no significant reduction of $L$. bulgaricus and B. animalis (BB-12) during the entire storage period of 21 days. Set-yoghurt made of Friesian milk showed significant reduction of $L$. bulgarius from day 01 to day 14 while set-yoghurt made of Jersey milk showed significant reduction from day 01 to day 07 and third week of the storage. However, the highest viability of L. bulgaricus (8.30 log cfu/g) was observed in set-yoghurt made from TW milk at the end of the storage period.

Viability of $B$. animalis (BB-12) was significantly reduced from day 01 to day 21 in set-yoghurt made of Jersey and Friesian milk while the lowest mean viability (6.11 log $\mathrm{cfu} / \mathrm{g}$ ) was recorded in setyoghurt prepared from Friesian milk. In general, Lactobacillus spp. and Bifidobacterium spp. grow slowly in fermented dairy product while viability of these microorganisms are highly associated with the unit operations undertake during the manufacturing process (Shah, 2000). As revealed in the present study, indigenous cattle milk has an ability to accelerate the growth and maintain the viability of these probiotic organisms than the milk of other two breeds. This could be attributed to the higher SNF content in milk obtained from TW and Lankan cattle breeds. Further it has been reported that starter bacteria growth can be accelerated through incorporation of micronutrients such as peptides and amino acids (Dave and Shah, 1998). Therefore, the improved availability of some micronutrients in TW and Lankan cattle milk could be a possible reason for increased probiotic counts in set-yoghurt made of indigenous cow milk. In order to maintain the consumer confidence on probiotic dairy products, it is necessary to ensure that they contain adequate amounts of probiotic bacteria specially Lactobacillus and Bifidobacterium spp. in the final product. Hence, the use of TW and Lankan cattle milk in probiotic dairy product formulations will make promising effects as probiotic carrier foods.

\section{Variations of titratable acidity, $\mathrm{pH}$ and syneresis of set-yoghurt}

Figure 1 illustrates the changes in titratable acidity of all four different set-yoghurts during the storage period. In the first day of storage, Jersey milk yoghurt demonstrated greater $(\mathrm{p}<0.05)$ titratable acidity values than other three treatments. Nonetheless, there was no difference in titratable acidity of set-yoghurts at the day 7 of storage. At the end of the storage period, set-yoghurt made of TW and Lankan cattle milk showed higher 
titratable acidity compared to yoghurt made of Jersey and Friesian milk. During the storage period of 21 days, $\mathrm{pH}$ of all set-yoghurts was gradually decreased within the acceptable range (Figure 2). All the $\mathrm{pH}$ and titratable acidity values of the setyoghurts made of four different breeds are in accordance with the standards (FDA, 2009). Sahan et al. (2008) and Kailasapathy (2006) observed similar trends in $\mathrm{pH}$ and titratable acidity of yoghurts during the entire storage. This observation is due to the accumulation of lactic acid by activity of starter bacteria (Vahedi et al., 2008). As per the observations of Jaros and Rohm (2003), acidification of yoghurts resulting in $\mathrm{pH}$ below 4.0 may lead to higher body and texture defects of the yoghurts. According to the $\mathrm{pH}$ values observed in the current study, $\mathrm{pH}$ of all four setyoghurts remained above 4.0 at the end of the 21 days of storage at $4 \pm 1^{\circ} \mathrm{C}$.

Syneresis (whey separation) is the major visible textural defect of set-yoghurt that occurs during the storage period which creates negative impact on consumer acceptance (Jumah et al., 2001). The results of the current study showed that there was a significant $(\mathrm{p}<0.05)$ difference in syneresis among the set-yoghurts made of four cattle breeds throughout the storage period of 21 days at $4 \pm 1{ }^{\circ} \mathrm{C}$ (Figure 3). Significantly $(\mathrm{p}<0.05)$ lower syneresis was observed in the set-yoghurt produced using TW and Lankan cattle milk while the highest syneresis was observed in the set-yoghurt produced with Friesian and Jersey milk throughout the storage period. Composition of the base milk used in the yoghurt production is one of the major factors affecting on whey separation of the yoghurt gels (Magdaleno, 2016). The highest syneresis observed in set- yoghurt made of Friesian milk and the lowest syneresis in yoghurt made of TW milk could be attributed to the lowest SNF content of Friesian milk and the highest SNF content of TW milk respectively, as shown in the milk composition analysis. Similarly, higher curd tension with low syneresis of buffalo milk curd has been observed due to higher levels of SNF in milk (Ganguly and Menon, 1971). Further, it has been reported that lower protein contents may cause broken coagulum resulting higher syneresis (Kroger, 1976).

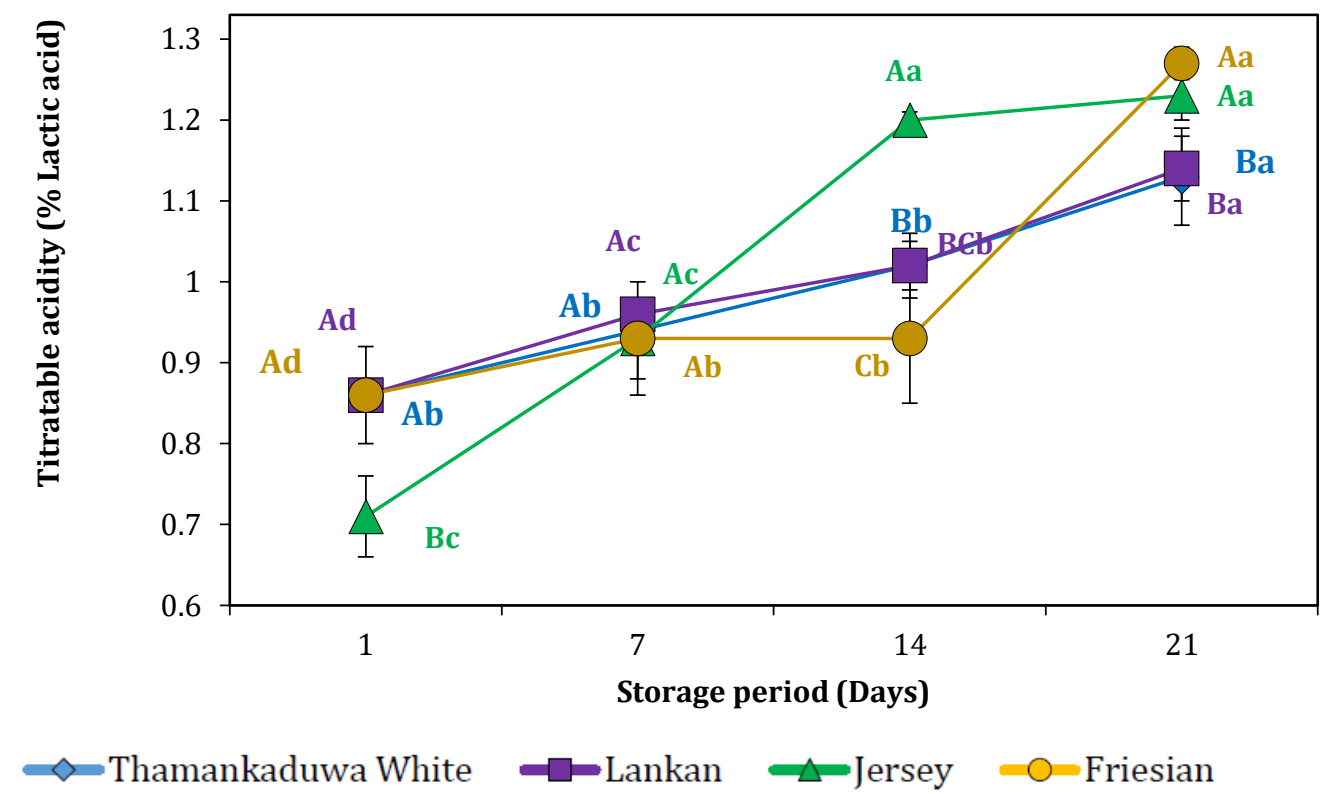

Figure 1: Changes of the titratable acidity of set-yoghurt made of TW, Lankan, Jersey and Friesian milk during storage of 21 days at $4 \pm 1^{\circ} \mathrm{C}$. Vertical lines represent standard deviations. ${ }^{A B C}$ Means with different uppercase letters are differ significantly $(p<0.05)$ between each set-yoghurt type for a particular day of storage. abc Means with different lowercase letters are significantly $(p<0.05)$ different between each day, for each treatment of set-yoghurt. 


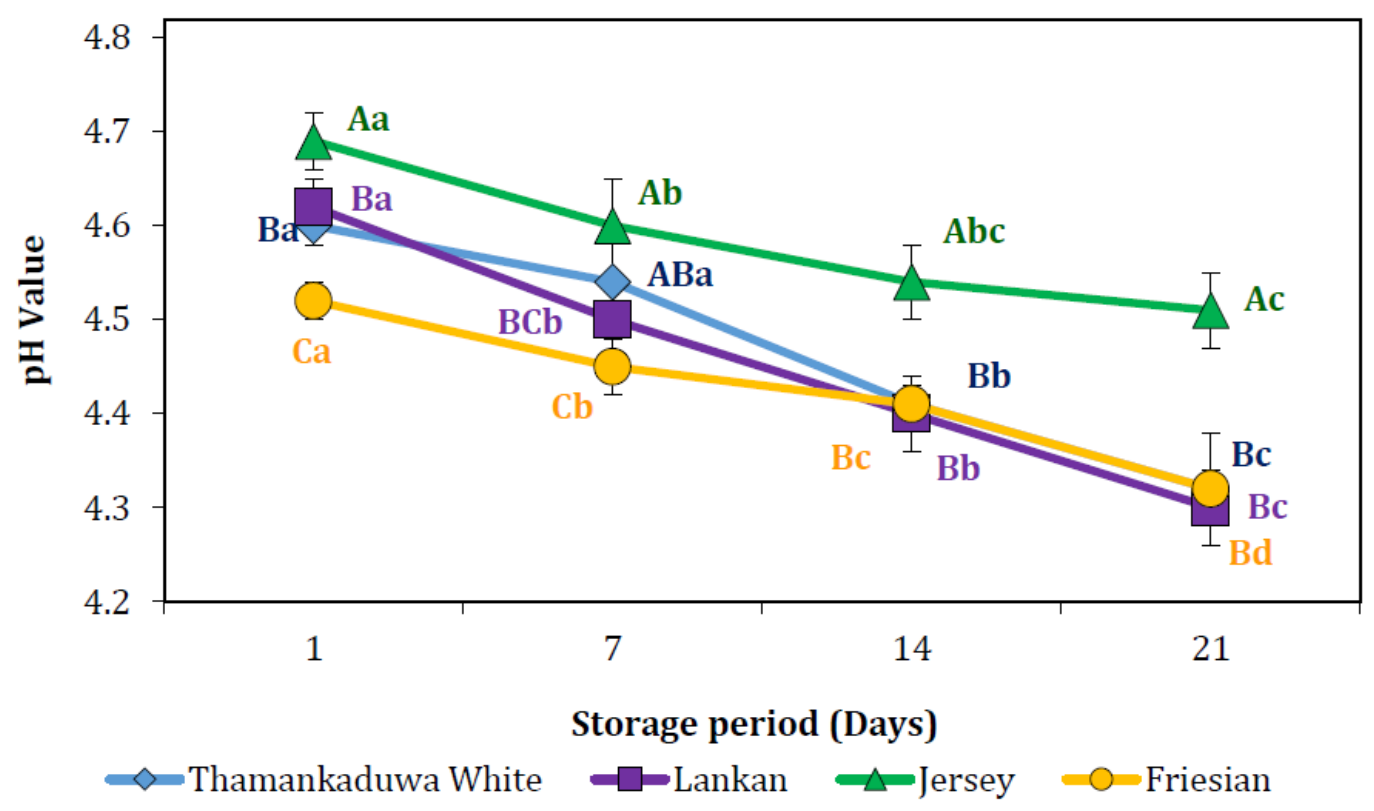

Figure 2: Changes of the pH value of set-yoghurt made of TW, Lankan, Jersey and Friesian milk during storage of 21 days at $4 \pm 1^{\circ} \mathrm{C}$. Vertical lines represent standard deviations. ${ }^{A B C}$ Means with different uppercase letters are differ significantly $(p<0.05)$ between each set-yoghurt type for a particular day of storage. abc Means with different lowercase letters are significantly $(\mathrm{p}<0.05)$ different between each day, for each treatment of set-yoghurt

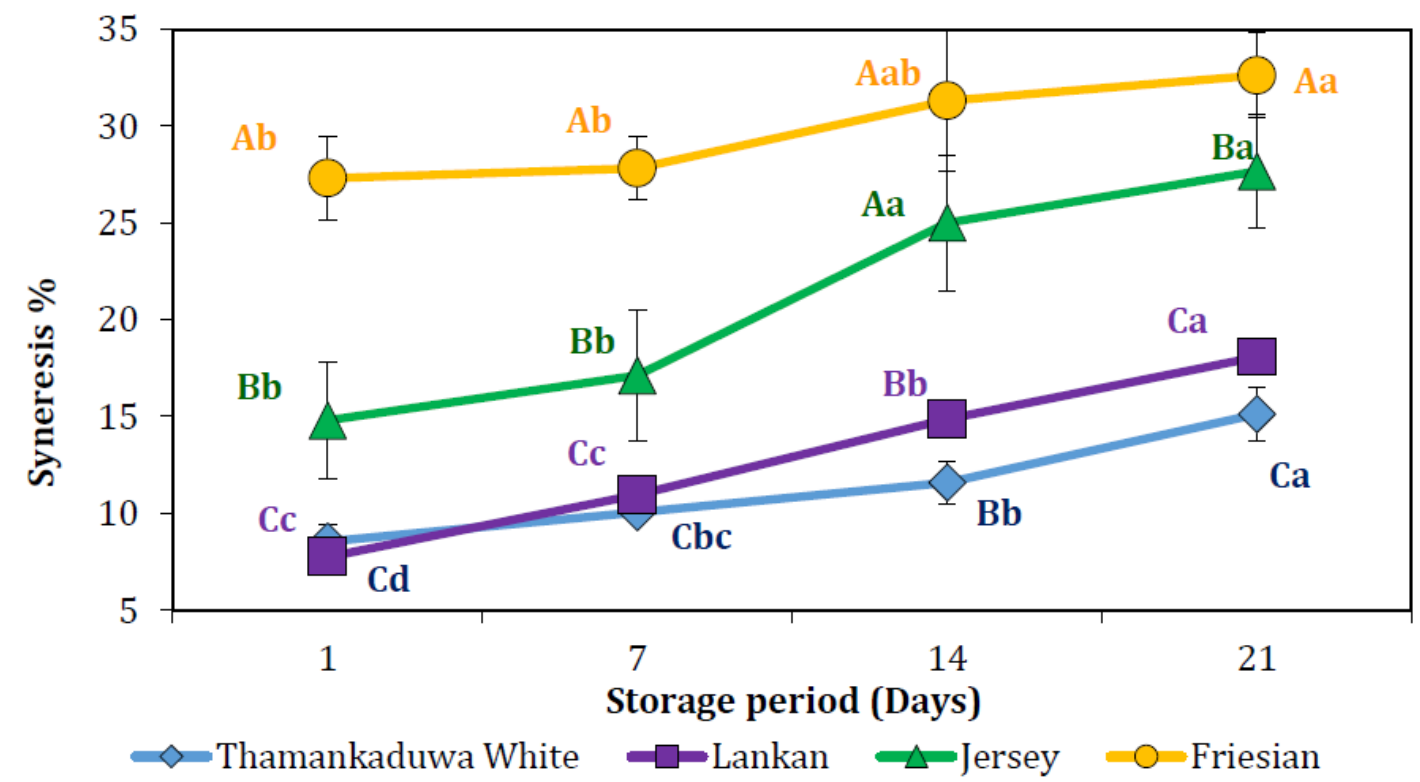

Figure 3: Changes of the syneresis value of set-yoghurt made of TW, Lankan, Jersey and Friesian milk during storage of 21 days at $4 \pm 1^{\circ} \mathrm{C}$. Vertical lines represent standard deviations. ${ }^{A B C}$ Means with different uppercase letters are differ significantly $(p<0.05)$ between each set-yoghurt type for a particular day of storage. abc Means with different lowercase letters are significantly $(p<0.05)$ different between each day, for each treatment of set-yoghurt 


\section{CONCLUSION}

Milk from the two indigenous breeds had the highest fat and SNF content compared to milk of two exotic breeds. Yoghurt made of TW and Lankan cattle milk had higher probiotic viability and lower syneresis during the storage period of 21 days. The results of the present study suggest the potential use of indigenous cow milk in development of probiotic dairy products with higher therapeutic value and improved technological properties. The

\section{REFERENCES}

Abeykoon, C. D., Rathnayake, R. M. C., Johansson, M., Silva, G. L. L. P., Ranadheera, C. S., Lundh, Å. and Vidanarachchi, J. K. (2016). Milk coagulation properties and milk protein genetic variants of three cattle breeds/types in Sri Lanka. Procedia Food Science, 6, 348351. doi:10.1016/j.profoo.2016.02.070

Adesina, K. (2012). Effect of breed on the composition of cow milk under traditional management practices in Ado-Ekiti, Nigeria. Journal of Applied Sciences and Environmental Management. 16(1), 55-49. doi:10.3923/pjn.2011.690.693

Agabriel, C., Coulon, J.B., Brunschwig, G., Sibra, C. and Nafidi, C., (1995). Relations between the quality of the milk delivered and the characteristics of the farms. Animal Productions. 8(4), 251-258.

Azari-Anpar, M., Payeinmahali, H., Daraei G. A. and Sadeghi M. A. (2017). Physicochemical, microbial, antioxidant, and sensory properties of probiotic stirred yoghurt enriched with Aloe vera foliar gel. Journal of Food Processing and Preservation. 41(5), e13209. doi:10.1111/jfpp.13209

Barłowska, J., Grodzicki, T., Topyła, B. and Litwińczuk, Z. (2009). Physicochemical properties of milk fat from three breeds of cows during summer and winter feeding. Archives Animal Breeding. 52(4), 356-363. doi:10.5194/aab-52-356-2009

Barłowska, J., Litwińczuk, Z., Król, J. and Kędzierska-Matysek, M., (2006). Fatty acid profile and minerals content in milk from cows of various breeds over spring-summer feeding period. Polish Journal of Food and Nutrition Sciences. 15, 3-16. findings provide an understanding regarding the diversified applications of indigenous cow milk while providing insights into the conservation of low productive but genetically valuable indigenous cattle breeds.

\section{ACKNOWLEDGEMENT}

This research study was funded by Rajarata University of Sri Lanka under university research grant: RJT/R\&PC/2018/Agri/R/06.

Bassiri, S., Taghizadeh, A., Angadji, L., Fard, M. D. and Tofigi, A. A. (2012). The comparison of lactation performance and milk fatty acid composition of Sarabi indigenous and Holstein cows. Journal of Cell and Animal Biology. 6(12), 182-187. doi:10.5897/ jcab12.048

Bergamaschi, M., Cipolat-Gotet, C., Stocco, G., Valorz, C., Bazzoli, I., Sturaro, E., Ramanzin, M. and Bittante, G. (2016). Cheesemaking in highland pastures: Milk technological properties, cream, cheese and ricotta yields, milk nutrients recovery, and products composition. Journal of Dairy Science. 99(12), 9631-9646. doi:10.3168/jds.2016-11199

Carić, M. Đ., Milanović, S. D. and Iličić, M. D. (2019). Novel trends in fermented dairy technology. Zbornik Matice srpske za prirodne nauke. (136), 9-21.

Chandrasiri, A. (2002). Country report on the animal genetic resources in Sri Lanka. Available at http://www.fao.org/3/a1250e /annexes/CountryReports/SriLanka.pdf [Accessed on 12.06.2020]

Cheruiyot, E. K., Bett, R. C., Amimo, J. O. and Mujibi, F. D. (2018). Milk composition for admixed dairy cattle in Tanzania. Frontiers in Genetics. 9, 1-12. doi:10.3389/fgene.2018.00142

Dannenberg, F. and Kessler, H. (1988). Effect of denaturation of $\beta$-lactoglobulin on texture properties of set-style nonfat yoghurt. Milchwissenschaft. 43(10), 632-635. doi:10.1007/978-94-009-3733-8_156

Dave, R. and Shah, N. (1998). Ingredient supplementation effects on viability of probiotic bacteria in yogurt. Journal of Dairy Science.81(11), 2804-2816. doi:10.3168/jds.s 0022-0302(98)75839-4 
Donkor, O. N., Nilmini, S., Stolic, P., Vasiljevic, T. and Shah, N. (2007). Survival and activity of selected probiotic organisms in set-type yoghurt during cold storage. International Dairy Journal. 17(6), 657-665. doi:10.1016/j.idairyj.2006.08.006

Duclos, D. and Hiemstra, S. J. (2010). State of local cattle breeds in Europe. Local cattle breeds in Europe, pp. 40-56. In: Hiemstra S.J., De Haas Y, Gandini M.G. (Ed) Local cattle breeds in Europe. Academic publishers, Wageningen, The Netherlands.

Ertem, H. and Çakmakçı, S. (2018). Shelf life and quality of probiotic yogurt produced with Lactobacillus acidophilus and Gobdin. International Journal of Food Science and Technology. 53(3), 776-783. doi:10.1111 /ijfs.13653

FDA, (2009). Milk and cream products and yogurt products. Food and Drug Administration Federal Register, 74: 2448

Felius, M. (1995). Cattle breeds: An encyclopedia, Misset, Doetin-chem, The Netherlands

Ganguly, A. and Menon, K. (1971). Electrolyte characteristics of Indian cow and buffalo milk. Indian Journal of Dairy Science. 24(3), 133142.

Haile, A., Joshi, B., Ayalew, W., Tegegne, A. and Singh, A. (2011). Genetic evaluation of Ethiopian Boran cattle and their crosses with Holstein Friesian for growth performance in central Ethiopia. Journal of Animal Breeding and Genetics. 128(2), 133-140. doi:10.1111/ j.1439-0388.2010.00882.x

Heck, J., Van Valenberg, H., Dijkstra, J. and Van Hooijdonk, A. (2009). Seasonal variation in the Dutch bovine raw milk composition. Journal of Dairy Science. 92(10), 4745-4755. doi:10.3168/jds.2009-2146

Islam, M., Alam, M., Islam, M., Khan, M., Ekeberg, D., Rukke, E. and Vegarud, G. (2014). Principal milk components in buffalo, holstein cross, indigenous cattle and Red Chittagong Cattle from Bangladesh. Asian-Australasian Journal of Animal Sciences. 27(6), 886. doi:10.5713/ajas.2013.13586

Jaros, D. and Rohm, H. (2003). Controlling the texture of fermented dairy products: the case of yoghurt. pp. 155-184. In: Smit G, (Ed.) Dairy
Processing. Woodhead Publishing Limited, Cambridge, UK.

Jumah, R., Shaker, R. and Abu-Jdayil, B. (2001). Effect of milk source on the rheological properties of yogurt during the gelation process. International Journal of Dairy Technology. 54(3), 89-93. doi:10.1046/ j.1364-727x.2001.00012.x

Kailasapathy, K. (2006). Survival of free and encapsulated probiotic bacteria and their effect on the sensory properties of yoghurt. LWT-Food Science and Technology. 39(10), 1221-1227. doi:10.1016/j.lwt.2005.07.013

Kebede, E. (2018). Effect of cattle breed on milk composition in the same management conditions. Ethiopian Journal of Agricultural Sciences. 28(2), 53-64.

Korhonen, H. (2009). Milk-derived bioactive peptides: From science to applications. Journal of Functional Foods, 1(2): 177-187. doi:10.1016/j.jff.2009.01.007

Kroger, M. (1976). Quality of yogurt. Journal of Dairy Science. 59(2), 344-350.

Madhubasani, G. B. L., Prasanna, P. H. P., Chandrasekara, A., Gunasekara, D. C. S., Senadeera, P., Chandramali, D. V. P and Vidanarachchi, J. K (2020). Exopolysaccharide producing starter cultures positively influence on microbiological, physicochemical, and sensory properties of probiotic goats' milk set-yoghurt. Journal of Food Processing and Preservation. 44(3), e14361. doi:10.1111/jfpp.14361

Magdaleno M. H. E. (2016). The effect of mechanical shear in ambient yoghurt. Master thesis. [online] Available at http://lup.lub.lu.se /student-papers/record/8881577 [Accessed on 26. 05. 2020)

Murphy, S. C., Martin, N. H., Barbano, D. M. and Wiedmann, M. (2016). Influence of raw milk quality on processed dairy products: How do raw milk quality test results relate to product quality and yield? Journal of Dairy Science. 99(12), 10128-10149. doi:10.3168/jds.201611172

Myburgh, J., Osthoff, G., Hugo, A., De Wit, M., Nel, K. and Fourie, D. (2012). Comparison of the milk composition of free-ranging indigenous African cattle breeds. South African Journal of Animal Science. 42(1), 1-14. 
Palladino, R. A., Buckley, F., Prendiville, R., Murphy, J., Callan, J. and Kenny, D. (2010). A comparison between Holstein-Friesian and Jersey dairy cows and their F1 hybrid on milk fatty acid composition under grazing conditions. Journal of Dairy Science. 93(5), 2176-2184. doi:10.3168/jds.2009-2453

Poulsen, N. A., Gustavsson, F., Glantz, M., Paulsson, M., Larsen, L. B. and Larsen, M. K. (2012). The influence of feed and herd on fatty acid composition in 3 dairy breeds (Danish Holstein, Danish Jersey, and Swedish Red). Journal of Dairy Science. 95(11), 6362-6371. doi:10.3168/jds.2012-5820

Ranadheera, C. S., Evans, C., Adams, M. and Baines, S. (2012). Probiotic viability and physicochemical and sensory properties of plain and stirred fruit yogurts made from goat's milk. Food Chemistry. 135(3), 1411-1418. doi:10.1016/j.foodchem.2012.06.025

Reddy, P. R. K., Reddy, A. N., Ramadevi, A. and Kumar, D. S. (2016). Nutritional significance of indigenous cow milk with regard to A2 beta casein-An overview. International Journal of Science, Environment and Technology. 5(5), 3376-3380.

Sahan, N., Yasar, K. and Hayaloglu, A. (2008). Physical, chemical and flavour quality of nonfat yogurt as affected by a $\beta$-glucan hydrocolloidal composite during storage. Food Hydrocolloids. 22(7), 1291-1297. doi:10.1016/j.foodhyd.2007.06.010

Shah, N. (2000). Probiotic bacteria: selective enumeration and survival in dairy foods. Journal of Dairy Science. 83(4), 894-907. doi:10.3168/jds.s0022-0302(00)74953-8

Silva, P., Herath, H. and Chandrasiri, A. (2008). Indigenous cattle types and production systems in Sri Lanka. Economic Review. 34,25-28.

Silva, P., Weerahewa, J., Gonzalez, I., Bouterakos, M. and Yanoma, Y. (2019). A policy report on Indigenous livestock and poultry for alleviating under-nutrition among women and children in rural farm-households of Sri Lankaby Food and Agriculture Organization and Faculty of Agriculture, University of Peradeniya, Sri Lanka. Available at http://www.fao.org/3/ca4666en/ca4666en. pdf [Accessed on 12.02.2020]
Singh, A. and Pratap, A. (2014). Comparison of Physicochemical Properties of Raw Milk from Indigenous and exotic cows at Allahabad. International Journal of Science and Research, 3, 1566-1568.

Sloan, E. (2014). The top ten functional food trends. Food Technology (Chicago), 68(4): 22-45

Summer, A., Malacarne, M., Martuzzi, F. and Mariani, P. (2002). Structural and functional characteristics of Modenese cow milk in Parmigiano-Reggiano cheese production. Annals of Faculty of Medical and Veterinary Di Parma, 22163-174.

Surono, I. and Hosono, A. (2011). Fermented milksTypes and standards of identity. pp. 470-495. In: Fuquay, J. W., Fox, P. F., Mc Sweeney, P. L. H. (Ed.) Encyclopedia of Dairy Sciences, Elsevier Academic Press, Cambridge, UK.

Vahedi, N., Tehrani, M. M. and Shahidi, F. (2008). Optimizing of fruit yoghurt formulation and evaluating its quality during storage. American Eurasian Journal of Agricultural and Environmental Sciences. 3(6), 922-927.

Welter, K. C., Martins, C. M. D. M. R., De Palma, A. S. V., Martins, M. M., Dos Reis, B. R., Schmidt, B. L. U. and Saran Netto, A. (2016). Canola oil in lactating dairy cow diets reduces milk saturated fatty acids and improves its omega3 and oleic fatty acid content. PloS One. 11(3), e0151876. doi:10.1371/journal.pone. 015 1876

Yang, L., Yang, Q., Yi, M., Pang, Z. and Xiong, B. (2013a). Effects of seasonal change and parity on raw milk composition and related indices in Chinese Holstein cows in northern China. Journal of Dairy Science. 96(11), 6863-6869.

Yang, T., Li, H., Wang, F., Liu, X. and Li, Q. (2013b). Effect of cattle breeds on milk composition and technological characteristics in china. Asian-Australasian Journal of Animal Sciences. 26(6), 896. doi:10.3168/jds.20136846

Yilmaz-Ersan, L. and Kurdal, E. (2014). The production of set-type-bio-yoghurt with commercial probiotic culture. International Journal of Chemical Engineering and Applications. 5(5), 402. doi:10.3168/ jds.2013-6846 